\title{
Land tenure and landscape change: a comparison of public-private lands in the southern High Plains
}

\author{
Todd D. Fagin 1*, Jacqueline M. Vadjunec ${ }^{2}$, Nicole M. Colston², Kathyrn Wenger² and Amy Graham²
}

\begin{abstract}
Introduction: Long-term drought in the southern Great Plains increases the vulnerability of coupled human-environment systems at a variety of scales. Developing better understandings of the dynamics at regional scales will become increasingly important as long-established land-use regimes break down in the face of climate change, resource depletion, and evolving governance. To demonstrate differential vulnerability during drought periods, this study hypothesized that observed increases in woody vegetation in grasslands would vary across land-tenure regimes. We argue that differences in State Trust Land governance, in part, lead to differential land management practices that contribute to landscape change.

Methods: The study area encompasses adjacent counties, Cimarron County in Oklahoma and Union County in New Mexico, with similar climate variability and agricultural economies. We analyzed National Land Cover Database (NLCD) land-cover maps from 1992 and 2011 to assess changes in landscape composition and structure between 1992 and 2011.

Results: During both years under consideration, each county in the study region, across various land-tenure regimes, was dominated by herbaceous vegetation. However, there were changes in both composition and structure across the whole study area, in particular losses of herbaceous vegetation and increases in woody vegetation. The greatest gains in woody vegetation occurred in State Trust Lands of Cimarron County. Overall, the data suggest a fragmentation of herbaceous vegetation and a coalescing of shrubland patches.

Conclusions: Research about the influence of land tenure on land management decisions, specifically the role of State Trust Land leases in overgrazing, informs the broader context of drought management in the southern Great Plains. Recommendations include continued research to highlight the specific mechanisms of land-tenure governance that drive landscape change.
\end{abstract}

Keywords: Drought, Land tenure, Agriculture, Landscape composition, Landscape structure, Southern Great Plains, Grasslands, Socio-ecological vulnerability, National Land Cover Database (NLCD)

\section{Introduction}

Agriculture is a primary driver of landscape change (Houghton 1994). Poor management decisions may increase land degradation through, for instance, habitat fragmentation, soil erosion, decreases in biodiversity, the introduction of invasive species, and loss of watershed capacity (Richards 1990; Bennett and Saunders 2010). In areas with high climatic variability, such as recurrent

\footnotetext{
* Correspondence: tfagin@ou.edu

'Oklahoma Biological Survey, University of Oklahoma, 111 E. Chesapeake St, Norman 73019, OK, USA

Full list of author information is available at the end of the article
}

drought events, implications of agricultural practices may become significant not only for the impacted region but also increasingly for larger areas, both at national and global scales (GLP 2005; IPCC 2013; Turner 2002; United Nation 2006). Studying drought-related landscape change at regional scales, therefore, offers insights potentially transferable to a broader range of contexts.

Long-term drought can increase the vulnerability of coupled human-environment systems, threatening the basic structure and functioning of environmental services, as well as a household's sustained use and socio-economic wellbeing provided by these services (Kasperson et al. 1996). 
Hence, vulnerability has both social and ecological components (Stone-Jovicich 2015) and can be defined as the inability of a (socio-environmental) system to adequately cope or rebound after a disturbance (Wisner et al. 2004). Drought, in particular, represents a slow-onset and often understudied type of disaster occurrence (Cutter 2004). Furthermore, institutional or governance policies may intervene in ways that impact both people and landscapes (Ostrom 2005; Walker et al. 2006).

In this paper, we explore the role of governance on landscape trajectories within two adjacent counties experiencing drought in the southern Great Plains: Cimarron County, OK, and Union County, NM (Fig. 1). Starting in 2000, the area endured a 15-year drought, with much of the region experiencing what the US National Drought Mitigation Center designated as "extreme" (D3) to "exceptional" (D4) drought-the most severe drought categories (U.S. Drought Monitor 2015). In an effort to demonstrate the differential vulnerability resulting from governance policies, which may be exasperated during drought periods, this study hypothesizes that observed increases in woody vegetation in grasslands will vary across land-tenure regimes. In particular, we predict that differences in State Trust Land governance lead to distinct land management practices that drive this landscape change.

\section{Study area}

Cimarron County, OK, and Union County, NM, adjacent counties in the southern Great Plains (Fig 1), share similar geographies, frontier cattle histories, population densities, and agricultural economies. Union County covers an area of $\sim 9903 \mathrm{~km}^{2}\left(\sim 3824 \mathrm{mi}^{2}\right)$ with an estimated 2014 population of 4297. By comparison, Cimarron County covers an area of $\sim 4752 \mathrm{~km}^{2}\left(\sim 1835 \mathrm{mi}^{2}\right)$ with an estimated 2014 population of 2294 (U.S. Census Bureau 2015a, b). However, the population density between the two counties remains roughly the same, $\sim 0.43-0.48 / \mathrm{km}^{2}\left(\sim 1.12-1.25 / \mathrm{mi}^{2}\right)$. Agriculture is the most important source of employment in both counties, with 468,296 ha (1,157,186 acres) and 796,166 ha (1,967,370 acres) of farmland in Cimarron and

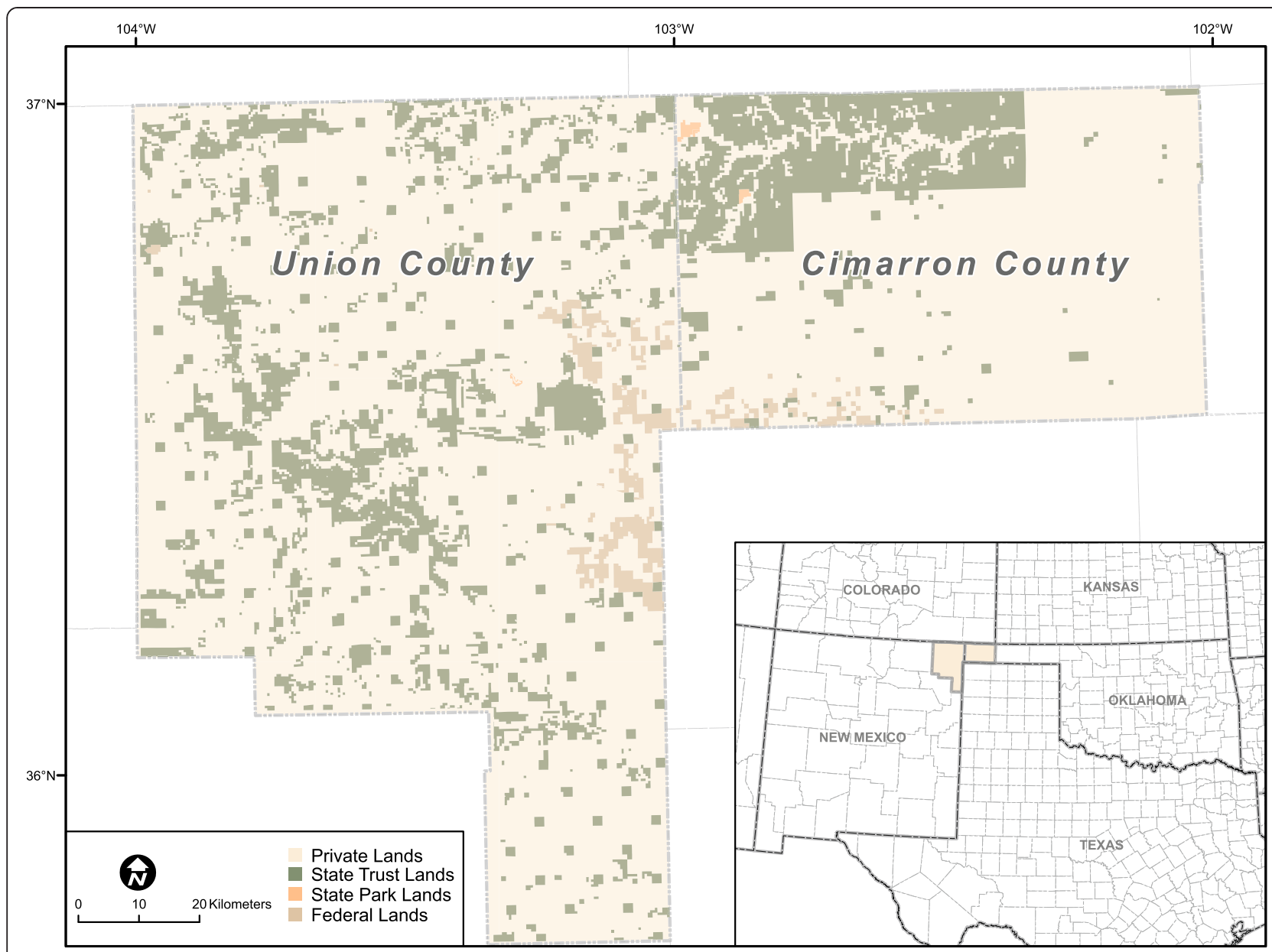

Fig. 1 The study area, Cimarron County, OK, and Union County, NM, in the southern Great Plains is a matrix of public and private lands. Data based on the Protected Areas Database of the United States (PAD-US) (USGS GAP Analysis Program, U.S. Geological Survey 2012) 
Union Counties, respectively (USDA-NASS 2014). Overall, 36.9 \% of Cimarron County's agricultural lands are classified as cropland, with a large proportion as Conservation Reserve Program (CRP) grasslands, as well as dry land and irrigated agriculture (USDA-NASS 2014). In Union County, $3.36 \%$ of agricultural lands are classified as cropland, the majority of which is irrigated agriculture (USDA-NASS 2014). Furthermore, the majority of land in both counties, 62.1 and 80.4 \%, in Cimarron and Union Counties, respectively, is dedicated to rangeland. However, the total market value and economic importance of these activities for both counties are extremely similar. Crops account for $\sim 17 \%$ of total market value in both counties, while livestock accounts for $\sim 83 \%$ (USDA-NASS 2014).

There are two distinct, but overlapping, regional landscapes across the study area, beginning with the High Plains in western Oklahoma eventually sloping up into the Southwestern Tablelands in northeast New Mexico. The High Plains, which occur throughout each county, are a semi-arid high plateau region classified as cold steppe (Köppen BSk) and characterized by shortgrass prairies (now predominately converted to croplands), coarse and sandy soils, and rolling, irregular plains. Elevation slopes from $1463 \mathrm{~m}(4800 \mathrm{ft})$ in the west to $732 \mathrm{~m}$ $(2400 \mathrm{ft})$ in the east. The far northwestern corner of Cimarron County (Black Mesa) and parts of northern and eastern Union County are dominated by the Southwestern Tablelands, a region characterized by dissected plains, hills, canyons, mesas, and badlands. More rugged and less arable than the High Plains, the Southwestern Tablelands are dominated by rangelands and consist of shortgrass prairies, juniper-pinyon woodlands, and scrub oak savannas (Woods et al. 2005; Griffin et al. 2006; Graham et al. 2013).

The average annual temperature in the two counties is $13.3{ }^{\circ} \mathrm{C}\left(56^{\circ} \mathrm{F}\right)$, with summer maximum temperatures averaging $31.5^{\circ} \mathrm{C}\left(88.7^{\circ} \mathrm{F}\right)$ and winter minimum temperatures averaging $-4.8{ }^{\circ} \mathrm{C}\left(23.3^{\circ} \mathrm{F}\right)$. The average annual precipitation ranges from approximately $381 \mathrm{~mm}$ (15 in.) to $508 \mathrm{~mm}(20 \mathrm{in}$.) with precipitation maxima occurring in May through August. However, starting in 2000, the area experienced drier than normal periods and ongoing drought conditions ranging from "abnormally dry" (D0) to "exceptional" (D4), with the most damaging D3-D4 drought conditions sustained from approximately 2008 to early 2015 (Lindsey 2008; U.S. Drought Monitor 2015).

In summary, both counties are comparable in terms of population densities, drought conditions, and farm economies (ranching and farming), as well as share similarities in rangeland use and physical geography. The study area allows for useful comparisons about the effects of land tenure on rangeland use and land-cover change, particularly woody plant encroachment, which can inform studies in drought vulnerability.

\section{Woody encroachment in the grasslands}

Within the past century and a half, woody plant abundance has increased at the expense of native grasslands in many parts of the world (Briggs et al. 2002; Van Auken 2009; Barnes et al. 2008). These increases in woody plant abundance have been attributed primarily to changes in fire regimes (Bragg and Hulbert 1976; Archer et al. 1995), livestock grazing (Schole and Archer 1997; Wilcox 2008), climate variability (Bahre and Shelton 1993; Archer et al. 1995), or a combination thereof (Miller and Rose 1995). The ecological consequences of these changes are numerous and include changes in the structure and function of habitat for various grassland and understory organisms (Fulendorf et al. 2002; Horncastle et al. 2005; Engle et al. 2006), decreases in productivity and herbaceous species diversity (Barnes et al. 2008; McKinley et al. 2008), changes in microclimate (Jackson et al. 1990; Barnes et al. 2008; McKinley et al. 2008), and changes in biogeochemical cycles (Barnes et al. 2008; McKinley et al. 2008).

Within Cimarron and Union Counties, the primary shrubby species most commonly associated with encroachment are walking stick cholla (Cylindropuntia imbricata (Haw.) F.M. Knuth), a tree-like cactus species native to the southwestern USA and northwestern Mexico, and one-seed juniper (Juniperus monosperma (Engelm.) Sarg.), a small evergreen shrub native to the Rocky Mountain foothills (Johnson and Hoagland 1999). Other encroaching woody plants include salt cedar (Tamarix spp.) and mesquite (Prosopis glandulosa Torr.). Increased dispersal of the species in these semi-arid climes has been linked to overgrazing. In particular, overgrazing creates gaps for seeds and stems to become established (Allen et al. 1991) and reduces fuel load and, thereby, fire that help restrict woody plant establishment (Paysen et al. 2000). As a result of overgrazing, dense cholla, mesquite, and juniper thickets often form in former herbaceous-dominated areas.

\section{Public lands in Oklahoma and New Mexico}

Land managers in the region must make land-use decisions based on complex economic and other external influences, such as changing policies regarding the lease and use of public lands. Since the outmigration of the region during the "Dust Bowl," ranches in the study area have steadily decreased in number and increased in size (Lowitt 2006). In particular, extra land is essential to sustain operations during times of drought, when stocking rates are low. To this end, ranchers often lease school land to sustain and/or expand operations. Over $20 \%(96,815$ ha) of land in Cimarron County is designated as State School Land, leased out by the Commissioners of the Land Office (CLO) "for the production of income for the support and maintenance of the common schools and the schools of higher education" (CLO (Commissioners of the Land Office) 2009). This 
represents almost one third of all State School Lands in Oklahoma (Oklahoma Ad Valorem 2006).

For the most part, ranch families have leased State School Lands for multiple generations (many over $80+$ years). In 1982, though, the Oklahoma Board of Education sued the CLO, which controls the State School Lands, over the constitutionality of state land lease policy. The Oklahoma Supreme Court ruled that ranchers should no longer have preference to school lands, nor should the Oklahoma legislature set maximum lease prices as they had for generations (Economist 1997). The resulting open-bidding policy has driven leasing prices beyond many ranchers' affordability, costing them access to significant portions of ranches historically managed by their families for generations (Lindsey 2008).

In Union County, by comparison, approximately $18 \%$ of the county $(176,763 \mathrm{ha})$ is state public land leased for state profit, while in Oklahoma, such public State Lands are called "State School Lands," and in New Mexico, such lands are called "State Trust Lands." For ease of reading, we use the term "State Trust Land" throughout this paper in regard to both. In both locations, lands were first set aside to fund the common schools starting with the Land Ordinance of 1785 (the original Federal Land grant), followed by the Enabling Act of 1906 in Oklahoma and 1910 in New Mexico (for a more complete history, see Culp et al. 2005; Vadjunec and Sheehan 2010).

Despite some similarities, the leasing policy in New Mexico radically differs from the open-bidding system in Oklahoma (CLO (Commissioners of the Land Office) 2014, see Table 1). In New Mexico, preference rights are attached to a household's deeded land (Culp et al. 2005). The household then has access to that leased land in perpetuity unless the family sells the rights to the land or breaks the 5-year lease. In the event that a lessee has not adequately secured the lease, however, there exists a mechanism for them to respond to a competitive bid (New Mexico State Land Office 2016a). New Mexico also offers financial incentives (e.g., reduced rents) for practicing sustainable practices, while Oklahoma does not. Lastly, during drought when stocking rates might be reduced, New Mexico allows lessees to apply for a reduction in rent, while Oklahoma does not.

Additionally, ranchers also lease federal lands in both counties, although to a lesser extent (roughly $1 \%$ of land are federal lands in both counties, see Table 1). Since rules for grazing leases and permits are set at the national level, ranchers in both counties are subject to the same set of regulations.

\section{Differential vulnerability}

Differences in leasing policy, we predict, have significant impacts on the land-use decisions of agriculturalists in each county. In Oklahoma, ranchers may have less incentive to
Table 1 Comparison of population, public lands, and State Trust Land policies in Cimarron County, OK, and Union County, NM

\begin{tabular}{|c|c|c|}
\hline & Cimarron County, OK & Union County, NM \\
\hline \multicolumn{3}{|l|}{ Households $(n)$} \\
\hline Population (2014) & 2294 & 4297 \\
\hline Households (2014) & 1575 & 2301 \\
\hline \multicolumn{3}{|l|}{ Public lands (ha/\%) } \\
\hline Total area & 96,815 & 176,763 \\
\hline State Trust Lands & $(20 \%)$ & $(18 \%)$ \\
\hline Total area & 1055 & 128 \\
\hline State parks & $(>1 \%)$ & $(>1 \%)$ \\
\hline Total area & 6019 & 23,686 \\
\hline Federal lands & $(1 \%)$ & $(2 \%)$ \\
\hline \multicolumn{3}{|l|}{ State Lands policy } \\
\hline Lease/term & $\begin{array}{l}\text { Less than } \\
5 \text { years }\end{array}$ & $\begin{array}{l}5 \text { years } \\
\text { or more }\end{array}$ \\
\hline Preference rights & No & $\begin{array}{l}\text { Yes, if secured properly } \\
\text { by lessee }\end{array}$ \\
\hline Open bidding & Yes & $\begin{array}{l}\text { Generally, no. Preference } \\
\text { rights given if secured } \\
\text { by lessee; otherwise, } \\
\text { lessee gets to match } \\
\text { any competitive bids }\end{array}$ \\
\hline $\begin{array}{l}\text { Sustainability } \\
\text { incentives offered }\end{array}$ & No & $\begin{array}{l}\text { Yes, reduced rents } \\
\text { (up to } 25 \% \text { off) }\end{array}$ \\
\hline $\begin{array}{l}\text { Fees reduced } \\
\text { during drought }\end{array}$ & No & $\begin{array}{l}\text { Yes, considered by } \\
\text { application }\end{array}$ \\
\hline
\end{tabular}

Sources: Culp et al. 2005; CLO 2015; US Census Bureau 2015a; b; Vadjunec (2015); New Mexico State Land Office 2016a, 2016b

practice sustainable grazing because they may not be able to renew their lease in 5 years, while in New Mexico, land managers generally do not have to worry about being outbid and losing their land. Consequently, agriculturalists in Cimarron County perceive increased vulnerability, due to "growing risk and changing ideas of stewardship," when it comes to State Trust Lands (Vadjunec and Sheehan 2010, p. 170). Indeed, such differential vulnerability appears to be both perceived and real. For instance, the residents of Cimarron County have received over \$27 million USD in Federal USDA disaster subsidies between 1995 and 2011, while the residents of Union County have only received a fraction thereof, \$ 9 million USD (EWG (Environmental Working Group) 2015). This difference in federal disaster funds is substantial given that Union County is twice the size of Cimarron County.

Overall, we predict that differing governance policies in the study area, specifically State Trust Lands, result in distinct land stewardship practices that may make people more or less vulnerable to land degradation, here woody plant encroachment in former grasslands, particularly in times of extreme climate vulnerability. Furthermore, since federal land leasing policies are similar in both counties, 
we do not expect to see significant differences in landscape change on federal lands. In order to test our hypothesis, we use landscape-level structure and compositional changes, specifically increases in woody plant cover and habitat fragmentation in erstwhile grassland, as an indicator for overall land management practices. Indeed, such increases, though likely not linked to a single causative factor, can often be linked to certain land management decisions, such as fire suppression or grazing intensification (Bahre 1991; Bahre and Shelton 1993; Van Auken 2009), and may be amplified during periods of climatic stress, such as drought (Fuhlendorf et al. 2008).

If land-tenure policies do not affect land management practices, particularly during periods of climatic stress, we would expect to see similar rates of woody plant encroachment across similar biophysical regimes throughout the rangelands of the study region and across the different land-tenure regimes of each county. Conversely, if such changes vary across the different land-tenure regimes but otherwise similar biophysical regimes, it may indicate that land-tenure policy does, indeed, influence land stewardship.

\section{Methods}

\section{Mapping vulnerability}

In an effort to map areas of socio-ecological vulnerability during times of drought, this study assessed landscape degradation in the form of woody plant encroachment across similar biophysical regimes using comparative land-cover maps from 1992 and 2011. We selected these years for comparison for several reasons. First, the 1992 land-cover dataset represents the land cover of the region during the first decade following changes in Oklahoma State Trust Land policies. Additionally, the 1992 dataset reflects the land cover during normal precipitation years (8 years before drought). Conversely, the 2011 data reflect the land cover after a decade of drier than normal conditions and post land-tenure regulation changes.

We used reclassified multi-temporal raster land-cover data from the National Land Cover Database (NLCD) in conjunction with a public land ownership database (USGS GAP Analysis Program, U.S. Geological Survey 2012) to determine land-cover trajectories with an emphasis on land tenure. More specifically, we reclassified 30-m 1992 (Fry et al. 2009) and 2011 (Homer et al. 2015) NLCD land-cover classes to a modified Anderson Level I classification scale (Anderson et al. 1976), identifying areas as water, built-up, barren, forest, shrubland, herbaceous, and cultivation. Changes in methodology, input data, and land-cover class definitions between the 1992 and 2011 NLCD products confounded direct comparisons between the datasets (Fry et al. 2009). To help rectify this matter, we used the NLCD 1992/2001 Retrofit Land Cover Change dataset (Fry et al. 2009). The dataset classifies each pixel with a "from" value, indicating its land-cover type in 1992, and a "to" value, indicating its value in 2001. Thusly, we used the datasets "from" value to reclassify to a modified Anderson Level I schema for 1992. Additionally, because the Retrofit dataset collapses the herbaceous and shrubland classes into a single class, we initially classified these areas as herbaceous. However, shrubland was an important category to capture, so we then utilized ancillary data sources (e.g., NLCD 1992 (Vogelmann et al. 2001) and digital orthophotographs) to delineate the 1992 shrubland cover.

Next, we used the Protected Areas Database of the United States (PAD-US version 1.3; USGS GAP Analysis Program, U.S. Geological Survey 2012) to delineate landtenure regimes. For each county, we identified federal lands (primarily National Grasslands and National Monuments), state parks, and State Trust Lands. All other lands were classified as private/others. However, state parks were negligible in each county, occupying less than $1 \%$ of the landscape in each county, so these lands were excluded from further analysis. Furthermore, while land ownership and boundaries do, indeed, change over time, the public/private land matrix remains relatively consistent as public lands rarely go up for sale in this region. Our analysis, therefore, assumes such changes were minimal during the time period under consideration.

For each land-cover dataset, we calculated basic patch and class-level landscape metrics, including number of patches; total, class, and patch area; percentage of landscape occupancy; and contiguity index (Gökyer 2013; McGarigal 2015). These metrics were calculated for the study region as a whole, at the individual county level, and for each land ownership class within the two counties for the two periods (1992 and 2011) under investigation. If our initial hypothesis is correct, we expect to see an increase in overall patchiness (more, yet smaller patches) and decrease in spatial connectedness (contiguity) of herbaceous vegetation and a concurrent decrease in patchiness and increase in spatial connectedness of the woody vegetation classes, particularly on State Trust Lands.

Lastly, in order to determine the potential drivers (e.g., land-tenure regimes, biophysical, or a combination thereof) of the observed landscape change at the various levels of analysis, we overlaid the two land-cover datasets and reclassified all pixels to either changed (when the pixel changed from herbaceous to shrubland) or no change (all other change combinations). We then generated 9496 random ( $X, Y$ coordinate) points throughout the study area, a value derived by the total number of pixels in the study area, a $95 \%$ confidence level, and margin of error of $1 \%$. To address potential spatial autocorrelation issues, points were placed at a minimum of $0.5 \mathrm{~km}$ from one another and proportionally distributed across each county and land-tenure type in areas classified as herbaceous in 1992. 
For each point, we determined the change category (change/no change), land-tenure regime (private/others, federal, or State Trust Lands, state park), and topographic wetness index (TWI) value (Sørensen et al. 2006). The latter was selected because it encompasses several biophysical characteristics, such as topography, hydrology, and edaphic conditions (Sørensen et al. 2006). We then ran a series of binary logistic regressions with change category as the dependent variable and land tenure and TWI values as the independent variables, to determine whether the observed change was driven primarily by biophysical variables of drought (e.g., TWI) or land-tenure regimes.

\section{Results}

Landscape composition 1992-2011

The 1992 landscape of the bi-county region was dominated by herbaceous vegetation with small amounts of cultivated lands, shrubland, and forest dispersed throughout (Figs. 2 and 3 and Table 2). Similar patterns emerged at the individual county level and across the various landtenure regimes thereof. However, whereas cultivation was the second largest land-cover class in Cimarron County (101,924 ha; $21 \%)$, cultivated lands occupied only a small fraction of lands (29,577 ha; $2.99 \%)$ in Union County. Conversely, woody vegetation classes of shrubland and

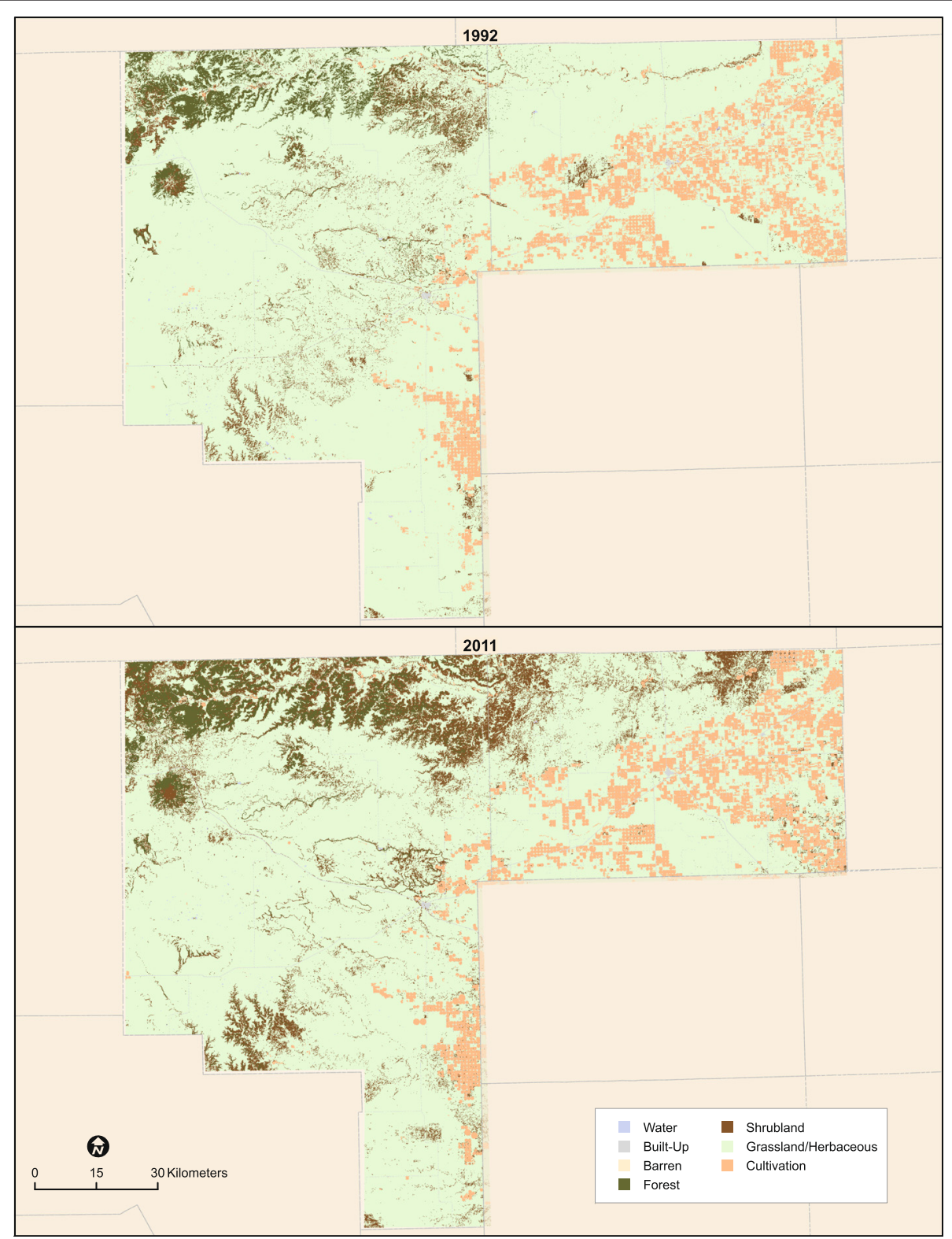

Fig. 2 Landscape composition in the study region, 1992 and 2011. Data based on the reclassified National Land Cover Database 1992 (Fry et al. 2009) and 2011 (Jin e al. 2013) data 


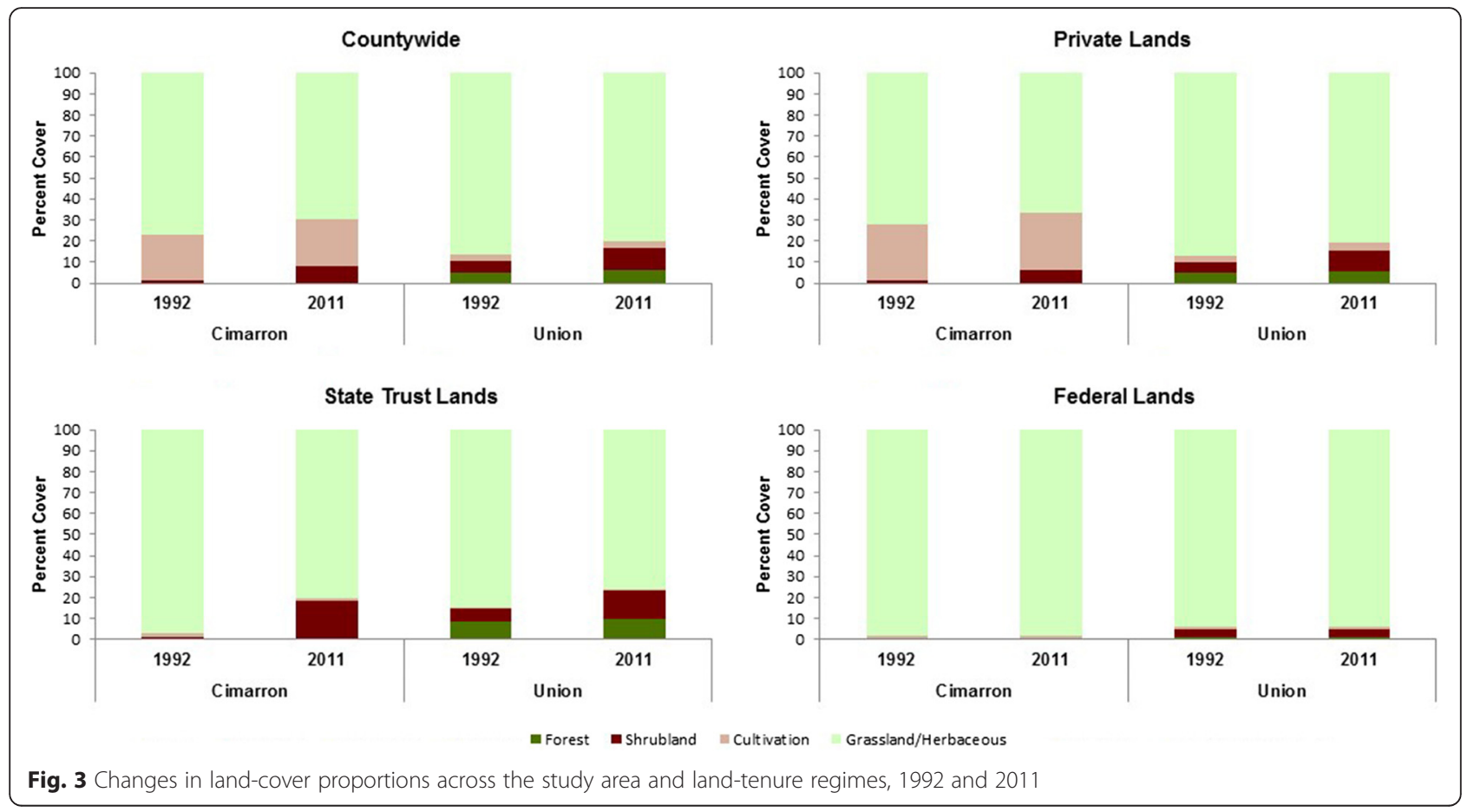

forest combined covered over $10 \%$ (103,048 ha) of Union County lands, while they occupied only $1.16 \%$ (5582 ha) of Cimarron County lands.

These patterns were further reflected at the land-tenure level in each of the counties. Within Cimarron County, both private lands and State Trust Lands were dominated by patches of herbaceous and, in the case of private lands, cultivated classes. This stood in stark contrast to the Union County private and State Trust lands, which consisted of numerous, albeit relatively small, patches of woody vegetation interspersed among larger patches of herbaceous land cover (Table 3). Within each county's federal lands, though, relatively large patches of herbaceous vegetation dominated.

By 2011, the landscape of the bi-county study region was still dominated by herbaceous vegetation $(\sim 1,113,589$ ha (75.52\%)), though at a smaller proportion than in 1992 (Figs. 2 and 3 and Table 2). In particular, both the shrubland and forest classes increased and, combined, they covered almost $15 \%$ of the bi-county landscape ( 199,696 ha). This pattern was further reflected at the individual county level. Both counties saw an increase in woody vegetation, particularly in the shrubland category, and a concurrent decrease in herbaceous land cover. These changes were greatest in Cimarron County, which saw a $631 \%$ increase in shrubland and $10.41 \%$ decrease in herbaceous vegetation, compared to a $104 \%$ increase in shrubland and a $7.45 \%$ decrease in herbaceous vegetation in Union County.
Herbaceous land cover remained the largest land-cover class across all land-tenure types within each county, though consistently in diminished quantities compared to the 1992 values. Across all land-tenure regimes within each county, the greatest gains were in the shrubland landcover class. This increase in woody vegetation was most accentuated in the Cimarron County State Trust Lands (Table 2).

\section{Landscape structure 1992-2011}

Structurally, the 1992 landscape of the bi-county region was characterized by several fairly large, contiguous patches of herbaceous vegetation (e.g., two patches $>475,000$ ha plus other large patches) dissected by many small, less spatially connected woody vegetation patches. County-wise, Cimarron County followed the patterns of the study regions, as a whole, while Union County was characterized by more, typically smaller, patches of herbaceous and woody vegetation types. Nonetheless, large swaths of the eastern portion of the Cimarron County landscape were also composed of large agricultural patches (Fig. 3, Table 3).

Similar patterns emerged at the land-tenure level in each of the counties in 1992. Within Cimarron County, both private lands and State Trust Lands were dominated by patches of herbaceous and cultivated lands. This stood in distinct contrast to the Union County private and State Trust lands, which consisted of numerous, albeit relatively small, patches of woody vegetation interspersed among 
Table 2 Comparison summary of land-cover change, countywide and by land-tenure regime (1992-2011). Values in hectares and percentage of landscape

\begin{tabular}{|c|c|c|c|c|c|c|}
\hline & Cimarron & & & Union & & \\
\hline \multicolumn{7}{|l|}{ Countywide } \\
\hline Land cover ha (\%) & 1992 & 2011 & Change & 1992 & 2011 & Change \\
\hline Herbaceous & $365,206(75.95)$ & $327,184(68.04)$ & $38,022(-10.41)$ & $849,754(85.90)$ & $786,405(79.50)$ & $63,349(-7.45)$ \\
\hline Cultivation & $101,924(21.20)$ & $101,800(20.66)$ & $124(-0.12)$ & $29,577(2.99)$ & $30,908(3.12)$ & $1311(-4.50)$ \\
\hline Shrubland & $5218(1.09)$ & $38,159(7.94)$ & $32,941(631.28)$ & $51,478(5.20)$ & $104,955(10.61)$ & $53,477(103.88)$ \\
\hline Forest & $363(0.08)$ & $362(0.08)$ & $1(-0.12)$ & $51,570(5.21)$ & $56,220(5.99)$ & $4650(9.01)$ \\
\hline \multicolumn{7}{|l|}{ State Trust Lands } \\
\hline Land cover ha (\%) & 1992 & 2011 & Change & 1992 & 2011 & Change \\
\hline Herbaceous & 93,608 (96.69) & $76,921(79.45)$ & $16,687(-17.83)$ & $148,510(84.02)$ & $133,585(75.57)$ & $14,925(-10.05)$ \\
\hline Cultivation & $1769(1.83)$ & $1593(1.65)$ & $175(-9.9)$ & $1214(0.69)$ & $1096(0.62)$ & $118(-9.67)$ \\
\hline Shrubland & $749(0.77)$ & $17,422(18.02)$ & $16,673(2226)$ & $11,220(6.35)$ & $24,418(13.81)$ & $13,198(117.64)$ \\
\hline Forest & $199(0.21)$ & $199(0.21)$ & $0(0)$ & $15,134(8.56)$ & $16,864(9.54)$ & $1730(-11.43)$ \\
\hline \multicolumn{7}{|l|}{ Federal lands } \\
\hline Land cover ha (\%) & 1992 & 2011 & Change & 1992 & 2011 & Change \\
\hline Herbaceous & $5878(97.64)$ & $5773(95.90)$ & $105(-1.78)$ & 22,116 (93.39) & $21,968(92.76)$ & $149(-0.67)$ \\
\hline Cultivation & $102(1.69)$ & $105(1.75)$ & $3(3.36)$ & $269(1.14)$ & $285(1.20)$ & $16(5.95)$ \\
\hline Shrubland & $0(0)$ & $3(0.05)$ & $3(n / a)$ & $857(3.62)$ & $963(4.07)$ & $106(12.35)$ \\
\hline Forest & $0(0)$ & $0(0)$ & $0(0)$ & $249(1.05)$ & $241(1.02)$ & $8(-3.32)$ \\
\hline \multicolumn{7}{|l|}{ Private lands } \\
\hline Land cover ha (\%) & 1992 & 2011 & Change & 1992 & 2011 & Change \\
\hline Herbaceous & $271,421(70.75)$ & $248,224(64.70)$ & $23,197(-8.55)$ & 680,958 (86.05) & $632,434(79.92)$ & $48,524(-7.12)$ \\
\hline Cultivation & $100,033(26.08)$ & $100,084(26.08)$ & $51(0.05)$ & 28,093 (3.55) & $29,524(3.73)$ & $1431(5.09)$ \\
\hline Shrubland & $4460(1.16)$ & $22,653(5.90)$ & 15,193 (407.92) & $39,607(5.00)$ & $80,014(10.11)$ & $40,407(102.02)$ \\
\hline Forest & $139(0.04)$ & $138(0.04)$ & $1(0.65)$ & $36,737(4.64)$ & $42,678(5.39)$ & $5941(16.17)$ \\
\hline
\end{tabular}

larger patches of herbaceous land cover (Fig 3, Table 3). Within each state's federal lands, though, relatively large patches of herbaceous vegetation dominated.

The landscape of the bi-county study region was less patchy in 2011 than in 1992, indicating a coalescing of previous disjunct patches. In particular, there was a decrease in the number of patches of each land-cover class and a concurrent increase in average patch area (Table 3 ). The greatest decrease in the number of patches came in the shrubland land-cover class, which saw a concurrent increase in average patch size and spatial connectivity, indicating a coalescing of previously isolated woody vegetation patches. The largest increase in average patch area, though, was in cultivation as center-pivot agriculture increased in the bi-county study region (Wenger 2016).

At the individual county level, though, both Cimarron County's herbaceous and shrubland vegetation become more patchy (more patches, smaller mean patch area, and less connectivity) than 1992, as large, relatively unbroken patches of herbaceous vegetation experienced woody encroachment. These changes were most pronounced on State Trust Lands, though private lands experienced similar trajectories. By contrast, Union County saw decreases in the number of patches and increases in the mean class area countywide and across different land-tenure regimes (Table 3).

\section{Drivers of landscape change}

The results of the binary logistic regression (see Table 4) indicate that in the bi-county study region, State Trust Lands were $\sim 2$ times more likely than private lands and $\sim 7$ times more likely than federal lands to change from herbaceous to shrubland $(p=0.000)$. Similarly, private lands were $\sim 3$ times more likely to change from herbaceous to shrubland than federal lands $(p=0.003)$. Overall, the model predicted that $15 \%$ of State Trust Lands, $8 \%$ of private lands, and $2 \%$ of federal lands would change from herbaceous to shrubland. When the topographic wetness index 
Table 3 Comparison of landscape metrics from 1992 and 2011 across the main land-tenure regimes in the two counties. A. number of patches; B. Average patch area (ha); C. Contiguity index $(\mathrm{Cl})$, a higher values indicates more spatial connectivity A.

\begin{tabular}{|c|c|c|c|c|c|c|c|c|c|c|c|}
\hline \multirow{2}{*}{$\begin{array}{l}\text { Land regime/ } \\
\text { county }\end{array}$} & \multirow[t]{2}{*}{ Year } & \multirow{2}{*}{$\begin{array}{l}\text { Herbaceous } \\
\text { (\#) }\end{array}$} & \multirow{2}{*}{$\begin{array}{l}\text { Cultivation } \\
(\#)\end{array}$} & \multirow{2}{*}{$\begin{array}{l}\text { Shrubland } \\
\text { (\#) }\end{array}$} & \multirow{2}{*}{$\begin{array}{l}\text { Forest } \\
(\#)\end{array}$} & \multirow[b]{2}{*}{ Union } & \multirow{2}{*}{$\begin{array}{l}2011 \\
1992\end{array}$} & 64 & \multirow{2}{*}{$\begin{array}{l}161 \\
15\end{array}$} & \multirow{2}{*}{$\begin{array}{l}3.7 \\
0.9\end{array}$} & \multirow{2}{*}{$\begin{array}{l}1.2 \\
0.45\end{array}$} \\
\hline & & & & & & & & 77 & & & \\
\hline Countywide & & & & & & & 2011 & 124 & 127 & 3.99 & 8.8 \\
\hline Cimarron & 1992 & 4081 & 3923 & 5106 & 312 & C. & & & & & \\
\hline \multirow{3}{*}{ Union } & 2011 & 5158 & 785 & 9065 & 311 & Land regime/ & \multirow[t]{3}{*}{ Year } & \multirow{3}{*}{$\begin{array}{l}\text { Herbaceous } \\
\text { (Cl) }\end{array}$} & \multirow{3}{*}{$\begin{array}{l}\text { Cultivation } \\
(\mathrm{Cl})\end{array}$} & \multirow{3}{*}{$\begin{array}{l}\text { Shrubland } \\
\text { (Cl) }\end{array}$} & \multirow{3}{*}{$\begin{array}{l}\text { Forest } \\
\text { (Cl) }\end{array}$} \\
\hline & 1992 & 13,097 & 2287 & 55,977 & 10,533 & county & & & & & \\
\hline & 2011 & 8061 & 371 & 27,320 & 6724 & Countywide & & & & & \\
\hline State land & & & & & & Cimarron & 1992 & 0.9623 & 0.8757 & 0.5831 & 0.7953 \\
\hline \multirow[t]{2}{*}{ Cimarron } & 1992 & 303 & 251 & 922 & 234 & & 2011 & 0.9372 & 0.9237 & 0.6928 & 0.5189 \\
\hline & 2011 & 1228 & 92 & 3625 & 234 & Union & 1992 & 0.964 & 0.8723 & 0.5804 & 0.7972 \\
\hline \multirow[t]{2}{*}{ Union } & 1992 & 4107 & 227 & 11,675 & 2622 & & 2011 & 0.6586 & 0.9322 & 0.6586 & 0.8165 \\
\hline & 2011 & 2881 & 42 & 6613 & 1971 & State land & & & & & \\
\hline Federal & & & & & & Cimarron & 1992 & 0.9802 & 0.8627 & 0.6228 & 0.4244 \\
\hline \multirow[t]{2}{*}{ Cimarron } & 1992 & 33 & 107 & 0 & 0 & & 2011 & 0.9254 & 0.9035 & 0.7196 & 0.4244 \\
\hline & 2011 & 36 & 72 & 2 & 0 & Union & 1992 & 0.9356 & 0.8362 & 0.59 & 0.8026 \\
\hline \multirow[t]{2}{*}{ Union } & 1992 & 208 & 150 & 883 & 13 & & 2011 & 0.9312 & 0.9152 & 0.6698 & 0.8176 \\
\hline & 2011 & 100 & 96 & 746 & 13 & Federal & & & & & \\
\hline Private & & & & & & Cimarron & 1992 & 0.9643 & 0.5824 & $\mathrm{Na}$ & $\mathrm{Na}$ \\
\hline \multirow[t]{2}{*}{ Cimarron } & 1992 & 3741 & 3558 & 4166 & 70 & & 2011 & 0.9598 & 0.6503 & 0.6571 & $\mathrm{Na}$ \\
\hline & 2011 & 3843 & 620 & 5401 & 69 & Union & 1992 & 0.9267 & 0.6799 & 0.6247 & 0.8872 \\
\hline \multirow[t]{2}{*}{ Union } & 1992 & 8773 & 1919 & 43,381 & 7881 & & 2011 & 0.9558 & 0.7294 & 0.4624 & 0.8756 \\
\hline & 2011 & 5065 & 233 & 19,933 & 4727 & Private & & & & & \\
\hline B. & & & & & & Cimarron & 1992 & 0.9415 & 0.876 & 0.6018 & 0.4325 \\
\hline \multirow{2}{*}{$\begin{array}{l}\text { Land regime/ } \\
\text { county }\end{array}$} & \multirow[t]{2}{*}{ Year } & \multirow{2}{*}{$\begin{array}{l}\text { Herbaceous } \\
\text { (ha) }\end{array}$} & \multirow{2}{*}{$\begin{array}{l}\text { Cultivation } \\
\text { (ha) }\end{array}$} & \multirow{2}{*}{$\begin{array}{l}\text { Shrubland } \\
\text { (ha) }\end{array}$} & \multirow{2}{*}{$\begin{array}{l}\text { Forest } \\
\text { (ha) }\end{array}$} & & 2011 & 0.9321 & 0.9233 & 0.6710 & 0.4328 \\
\hline & & & & & & Union & 1992 & 0.9583 & 0.8728 & 0.5686 & 0.7788 \\
\hline Countywide & & & & & & & 2011 & 0.9547 & 0.9321 & 0.6467 & 0.7999 \\
\hline
\end{tabular}

\begin{tabular}{cccccc}
$*$ \\
\multirow{3}{*}{ Union } & 2011 & 63 & 130 & 4.2 & 1.2 \\
& 1992 & 65 & 13 & 0.9 & 5.0 \\
& 2011 & 98 & 83 & 4.0 & 8.8
\end{tabular}

State land

\begin{tabular}{llllll} 
Cimarron & 1992 & 308 & 7 & 0.8 & 0.8 \\
& 2011 & 63 & 17 & 4.8 & 0.8 \\
\multirow{3}{*}{ Union } & 1992 & 36 & 5 & 1 & 5.7 \\
& 2011 & 46 & 26 & 3.7 & 8.5
\end{tabular}

Federal

$\begin{array}{llllll}\text { Cimarron } & 1992 & 33 & 1.2 & 0 & 0 \\ & 2011 & 160 & 1.8 & 1.5 & 0 \\ \text { Union } & 1992 & 106 & 1.8 & 0.97 & 19.0 \\ & 2011 & 220 & 2.9 & 1.3 & 19 \\ \text { Private } & & & & & \\ \text { Cimarron } & 1992 & 71 & 28 & 1.1 & 1.2\end{array}$

Table 3 Comparison of landscape metrics from 1992 and 2011 across the main land-tenure regimes in the two counties. A. number of patches; B. Average patch area (ha); C. Contiguity index $(\mathrm{Cl})$, a higher values indicates more spatial connectivity (Continued)

(TWI) was incorporated into the model to determine whether these observed changes may actually be driven by biophysical conditions rather than land tenure, we found that change was always associated with lower TWI value (i.e., flatter, less prone to excessive drainage) areas but did not diminish the importance of land tenure on these observed changes.

The model predicted similar results at the individual county level. Within Cimarron County, State Trust Lands were $\sim 2$ times more likely than private lands to change from herbaceous to shrubland $(p=0.000)$, with a predicted $18 \%$ of State Trust Lands and $7 \%$ of private lands so changing. However, our samples did not include any federal lands in Cimarron County that changed from herbaceous to shrubland, so federal lands were excluded from these analyses. 
Table 4 Binary logistic regression results. A. Land tenure only; B. Land tenure and topographic wetness index (TWI)

\begin{tabular}{|c|c|c|c|}
\hline \multicolumn{4}{|l|}{ A. } \\
\hline Bi-county & $B$ & $p$ & Odds ratio \\
\hline \multicolumn{4}{|c|}{ State trust vs. private } \\
\hline Land tenure & 0.714 & 0.000 & 2.042 \\
\hline \multicolumn{4}{|c|}{ State trust vs. federal } \\
\hline Land tenure & 1.942 & 0.000 & 6.976 \\
\hline \multicolumn{4}{|c|}{ Private vs. federal } \\
\hline Land tenure & 1.1229 & 0.003 & 3.416 \\
\hline Cimarron County & $B$ & $p$ & Odds ratio \\
\hline \multicolumn{4}{|c|}{ State trust vs. private } \\
\hline Land tenure & 0.994 & 0.000 & 2.701 \\
\hline \multicolumn{4}{|c|}{ State trust vs. federal } \\
\hline Land tenure & $\mathrm{Na}$ & $\mathrm{Na}$ & $\mathrm{Na}$ \\
\hline \multicolumn{4}{|c|}{ Private vs. federal } \\
\hline Land tenure & $\mathrm{Na}$ & $\mathrm{Na}$ & $\mathrm{Na}$ \\
\hline Union County & $B$ & $p$ & Odds ratio \\
\hline \multicolumn{4}{|c|}{ State trust vs. private } \\
\hline Land tenure & 0.533 & 0.000 & 1.703 \\
\hline \multicolumn{4}{|c|}{ State trust vs. federal } \\
\hline Land tenure & 1.549 & 0.000 & 4.708 \\
\hline \multicolumn{4}{|c|}{ Private vs. federal } \\
\hline Land tenure & 1.017 & 0.003 & 2.764 \\
\hline \multicolumn{4}{|l|}{ B. } \\
\hline Bi-county & $B$ & $p$ & Odds ratio \\
\hline \multicolumn{4}{|c|}{ State trust vs. private } \\
\hline Land tenure & 0.547 & 0.000 & 1.728 \\
\hline TWI & -0.441 & 0.000 & 0.643 \\
\hline \multicolumn{4}{|c|}{ State trust vs. federal } \\
\hline Land tenure & 1.573 & 0.000 & 4.822 \\
\hline TWI & -0.408 & 0.000 & 0.665 \\
\hline \multicolumn{4}{|c|}{ Private vs. federal } \\
\hline Land tenure & 0.994 & 0.018 & 2.702 \\
\hline TWI & -0.450 & 0.174 & 0.026 \\
\hline Cimarron County & $B$ & $p$ & Odds ratio \\
\hline \multicolumn{4}{|c|}{ State trust vs. private } \\
\hline Land tenure & 0.625 & 0.000 & 1.868 \\
\hline TWI & -0.352 & 0.000 & 0.703 \\
\hline \multicolumn{4}{|c|}{ State trust vs. federal } \\
\hline Land tenure & $\mathrm{Na}$ & $\mathrm{Na}$ & $\mathrm{Na}$ \\
\hline TWI & $\mathrm{Na}$ & $\mathrm{Na}$ & $\mathrm{Na}$ \\
\hline \multicolumn{4}{|c|}{ Private vs. federal } \\
\hline Land tenure & $\mathrm{Na}$ & $\mathrm{Na}$ & $\mathrm{Na}$ \\
\hline TWI & $\mathrm{Na}$ & $\mathrm{Na}$ & $\mathrm{Na}$ \\
\hline Union County & $B$ & $p$ & Odds ratio \\
\hline
\end{tabular}

Table 4 Binary logistic regression results. A. Land tenure only; B. Land tenure and topographic wetness index (TWI) (Continued)

\begin{tabular}{llll} 
State trust vs. private & & & \\
Land tenure & 0.474 & 0.000 & 1.607 \\
TWI & -0.496 & 0.000 & 0.609 \\
State trust vs. federal & & & \\
Land tenure & 1.270 & 0.003 & 3.561 \\
TWI & -0.417 & 0.000 & 0.659 \\
Private vs. federal & & & \\
Land tenure & 0.735 & 0.082 & 2.085 \\
TWI & -0.512 & 0.000 & 0.599 \\
\hline
\end{tabular}

In Union County, State Trust Lands were $\sim 2(p=0.000)$ times more likely to change from herbaceous to shrubland than private lands and $\sim 5$ times more likely to change from herbaceous to shrubland than federal lands. Private lands were also $\sim 3$ times more likely to change than federal lands $(p=0.015)$. The binary logistic regression model predicted that $13 \%$ of State Trust Lands, $8 \%$ of private lands, and $3 \%$ of federal lands within Union County would change from herbaceous to shrubland.

\section{Discussion}

We predicted that differential governance policies in the study area, specifically State Trust Lands, result in distinct land stewardship practices, making people more or less vulnerable to land degradation (measured as woody plant encroachment) particularly in times of extreme climate vulnerability. While the land-cover datasets we used for these analyses do not differentiate between specific shrubland types, they nonetheless provide insight into the complex land cover and governance dynamics occurring within the study area. The increases in shrubland and concurrent loss of herbaceous vegetation seem to show high rates of woody plant encroachment during the period of investigation. Additionally, while disentangling the causal mechanisms of these changes is difficult, the different rates of change within each county and under different land tenures may implicate governance (i.e., local and state politics) as a compounding factor in woody plant encroachment.

Indeed, discussions with agriculturalists (Vadjunec 2015; Fagin 2016) suggest that woody plant encroachment has been exacerbated by the extended drought coupled with certain land management decisions (e.g., overgrazing) and complex, constraining, and often conflicting governance practices, particularly on State Trust Lands. In periods of extreme moisture deficits, grazing pressure (ratio of demand/availability of forage) increases, even though the state attempts to control such measures by setting stocking rates. Land managers often must balance the needs of 
short-term profit over long-term ecological health, especially during recovery periods when stocking rates may technically increase, but historically ranchers would usually let the land rest to ensure long-term recovery. When permanency on a track of land is not guaranteed, land managers may be more reluctant to cull herds to more sustainable levels, to follow set grazing guidelines, or to let State Trust Land rest as needed, resulting in overgrazing and, thus, presumably woody plant encroachment.

This is not to say that land managers are necessarily poor land stewards but rather that the differential governing system of State Trust Lands may offer both opportunities and constraints to land managers. For instance, in Union County, NM, land managers' long-term security due to the leasing process enables them to make longerterm management decisions. In Cimarron County, OK, on the other hand, controversial leasing policies lead to insecurity and may make it more difficult for land managers to consider long-term sustainability. Given the insecurity generated by leasing policies regarding State Trust Lands in Cimarron County, there is little incentive for land managers to think long term, even though many state that they would like to, or claim to have done so before the openbidding system was adopted. As Vadjunec and Sheehan (2010, p. 170), who have studied State Trust Land policies in Cimarron County, explain, "with their future now uncertain (in five-year increments with no preferential treatment given to the lessee), many land managers express difficulty caring for leased land like it was their own, as they have done in the past."

Additionally, governance rules also vary substantially between the two counties/states. For instance, Harding and Union Counties, NM, are part of the Canadian River Riparian Forest Restoration Project (other counties outside of Cimarron County in Oklahoma are part of the project as well). The Canadian River Riparian Forest Restoration Project provides incentives for agriculturalists to remove water-thirsty shrub species, such as salt cedar (Harding County 2016). In fact, the "New Mexico Statewide Natural Resources Assessment, Strategy, and Response Plan" offers programs that promote "management on private and state lands that reduces tree competition (ENMRD Forestry Division 2010, p. 45, italics, our emphasis)." Furthermore, the New Mexico State Land Office (2016b) states that it "supports the use of prescribed fire," as well as "forest health thinning and restoration projects target[ing] state trust lands with an unhealthy density of trees and/or undesirable species composition to improve ecological function." However, Oklahoma does not openly promote such management on State Trust Lands, unless under highly controlled circumstances. Specifically, CLO policy states that no conservation work can be completed on State Trust Land without written consent first (CLO (Commissioners of the Land Office) 2014).
Indeed, one rancher in Cimarron County described a situation where he removed cholla on State Trust Lands (at his own time and expense), only to receive a letter from the CLO informing him that if he continued to remove cholla from his leased land, he would need to add a snow fence at his own expense to capture precipitation (Vadjunec 2015). Whereas discussions with residents in Union County suggest that in many ways they are encouraged to treat State Trust Lands "as their own" to some extent in their management decisions, Oklahoma policy distinctly separates private and state land management to a much greater extent. Furthermore, discussions with agriculturalists in Cimarron County reveal a common complaint - that their hands are tied when it comes to making land management decisions on State Trust Lands (see also Vadjunec and Sheehan 2010). As a result, governance in both counties appears to be distinct in reality and/or practice (formally and informally).

\section{Limitations}

For this analysis, we used the best (and most recent), readily available multi-temporal data for the bi-county study area. Changes in NLCD methodology, input data, and land-cover class definitions between the 1992 and 2001 NLCD products, though, make direct comparisons between the datasets more complicated (Fry et al. 2009). The reclassification of the NLCD 1992/2001 Retrofit Land Cover Change dataset (Fry et al. 2009) attempted to address this issue; grassland and shrub cover were aggregated into a single class in the Retrofit dataset. This was problematic for our specific analysis because the phenomenon we were most interested in was woody plant encroachment. We overcame this data gap by incorporating the shrubland land-cover class from the NLCD 1992 (Vogelmann et al. 2001) into our reclassified 1992 dataset. However, we expect this may have resulted in an underestimation of overall shrubland cover, for the 1992 imagery, specifically.

As a result, the amount of change in woody plant encroachment between 1992 and 2011 may be overestimated in the current analysis. However, we note that the uncovered relationships and patterns of change still hold weight. Since the limitations stated above are presumably uniform throughout the study area, we would expect to see similar landscape dynamics throughout. Yet, overall, we still see a statistically significant and higher rate of shrubland change in Cimarron County, in general, and within Cimarron County State Trust Lands, specifically. Furthermore, the observed structural and compositional differences suggest the importance of land tenure to landscape change in the study area, regardless of any potential issues with the 1992 dataset. These additional analyses support our current conclusion regarding greater woody plant encroachment occurring in these areas. To better 
estimate the rates of change, in the future, we plan on using high-resolution aerial photography and an image object-based classification (Vadjunec et al. 2015).

\section{Conclusions}

This study shows that governance decisions being made at the state level influence the practices of agriculturalists at the local level. These decisions, in turn, have implications for both individuals and the structure and functions of landscapes. In Cimarron County, agriculturalists perceive greater vulnerability surrounding their use of State Trust Lands (Vadjunec and Sheehan 2010). Beyond their perceptions regarding vulnerability to what they perceive to be unfair leasing policies, agriculturalists in Cimarron County also receive significantly greater Federal USDA disaster subsidies. However, these state- and local-level land-use decisions have wide-reaching regional effects as seen through regional-level landscape change (i.e., the preponderance of woody plant encroachment on State Trust Lands in Cimarron County, OK).

Public lands, including state and federal lands, are a staple of ranching and farming in the American West. Understanding the governance of such lands and how they impact land use, land management, livelihoods, and landscapes is increasingly important in the face of drought and increasing vulnerabilities due to climate change. State Trust Lands are particularly concentrated in the American West. As Culp and colleagues (2005, p. 54) explain, "nine of the eleven Western states-Arizona, Colorado, Idaho, Montana, New Mexico, Oregon, Utah, Washington, and Wyoming-hold nearly 85 percent, or almost 40 million acres, of the remaining trust lands in the lower forty-eight states."

A comparative approach in the study of landscape changes in distinctively different locales increases the transferability of research findings. Focusing on adjacent counties under different land-tenure systems presents an opportunity to examine the changes actors face in many of the Western grasslands on both a local and a regional basis. The research site offers a unique opportunity to further explore this issue because Cimarron County is the only county in America that shares a border with four states: New Mexico, Colorado, Texas, and Kansas. This area is increasingly vulnerable to cyclical drought, growing impacts from mechanized agriculture and underground water depletion, and historical and changing land-use trajectories (Savage 2004). Developing better understandings of the complex human-environment dynamics at work and also how best to uncover such relationship between people and landscapes will become increasingly important as long-established land-use regimes break down in the face of climate change, resource depletion, and evolving governance.

\section{Acknowledgements}

We are grateful to the people of Cimarron and Union Counties for sharing their time and knowledge with us. We also thank Brenda D. Phillips for the help with a much earlier draft of this paper.

\section{Funding}

This research has generously been funded by a National Science Foundation (NSF) research grant (\#CMMI-1266381) and fellowship (\#SMA-1415368). Any opinions, findings, and conclusions or recommendations expressed in this paper are those of the authors and do not necessarily reflect the views of the National Science Foundation.

\section{Authors' contributions \\ TDF contributed to the research design, methodology, fieldwork, analysis, and paper write-up. JMV contributed to the research design, methodology, fieldwork, and paper write-up. NMC contributed to the fieldwork and paper write-up. Both KW and AG are graduate research assistants who participated in the fieldwork. Each also helped in the early drafts of the manuscript. All authors read and approved the final manuscript.}

\section{Authors' information}

TDF, a geographer by training, works at the Oklahoma Biological Survey at the University of Oklahoma. His research interests include land-use/land-cover change, historical vegetation reconstructions, biogeography and landscape ecology, habitat fragmentation, geographic information systems, and remote sensing.

JMV is an associate professor in the Department of Geography at Oklahoma State University. Her interests include environmental governance, common (public-private) property and natural resource management, land use and livelihoods in traditional agricultural communities in the Americas, and participatory and mixed research methods.

NMC is a post-doctoral research fellow in the Department of Geography at Oklahoma State University. Her interests include environmental science, environmental education, citizen science, and environmental

communication.

KW is a Ph.D. student at Oklahoma State University in the Department of Geography. Her interests are disaster resilience and adaptation, governance, land-use/land-cover change, and mixed research methods.

AG is a Ph.D. student at Oklahoma State University in the Department of Geography. Amy is interested in better understanding how gender influences drought perceptions, as well as understanding how drought impacts both men and women differently.

\section{Competing interests}

The authors declare that they have no competing interests.

\section{Author details}

${ }^{1}$ Oklahoma Biological Survey, University of Oklahoma, 111 E. Chesapeake St, Norman 73019, OK, USA. ²Department of Geography, Oklahoma State University, 337 Murray Hall, Stillwater 74078, OK, USA.

Received: 20 May 2016 Accepted: 9 August 2016

Published online: 18 August 2016

\section{References}

Allen L, Allen E, Kunst C, Sosbee R (1991) A diffusion model for dispersal of Opuntia imbricate (cholla) on rangeland. J Ecol 79(4):1123-1135

Anderson J, Hardy E, Roach J, Witmer R (1976) A land use and land cover classification system for use with remote sensor data. Geological Survey Professional Paper 964. United States Government Printing Office, Washington

Archer S, Schimel D, Holland E (1995) Mechanisms of shrubland expansion: land use, climate or $\mathrm{CO}_{2}$ ? Climatic Change 29:91-99

Bahre C (1991) A legacy of change: historic human impact on vegetation in the Arizona borderland. University of Arizona Press, Tucson

Bahre C, Shelton M (1993) Historic vegetation change, mesquite increases, and climate in southeastern Arizona. J Biogeogr 20:489-504

Barnes P, Liang S, Jessup K, Ramirez P, D'Souza L, Elliott K, Phillips P (2008) Ecological impacts of Ashe juniper on subtropical savanna parklands and woodlands. In: Van Auken O (ed) Western North American Juniperus communities: a dynamic vegetation type. Springer, New York, pp 133-155 
Bennett A, Saunders D (2010) Habitat fragmentation and landscape change In: Navjot S, Sodhi S, Ehrlich P (eds) Conservation biology for all. Oxford University Press, Oxford, pp 88-106

Bragg T, Hulbert L (1976) Woody plant invasion of unburned Kansas bluestem prairie. J Range Manage 29(1):19-24

Briggs J, Hoch G, Johnson L (2002) Assessing the rate, mechanisms, and consequences of the conversion of tallgrass prairie to Juniperus virginiana forest. Ecosystems 5:578-586

CLO (Commissioners of the Land Office) (2009) Annual report: growth the trust. CLO, Oklahoma City

CLO (Commissioners of the Land Office) (2014) Unofficial Administrative Rules OAC 385:1-1-1 through 385:40-1-12. CLO, Oklahoma City, Available from https://clo.ok.gov/wp-content/uploads/2015/02/CLO-Administrative-Rules2014-Unofficial-Website.pdf (Accessed 4/2015)

Culp P, Conradi DB, Tuell CC (2005) Trust land in the American West: a legal overview and policy assessment. Lincoln Institute of Land Policy, Cambridge

Cutter S (2004) Are we asking the right questions? In: Perry R, Quaramtelli E (eds) What is a disaster: new answers to old questions. Xlibris, Philadelphia, pp 39-48

Economist T (1997) For cattle or schools. Economist 342(8000):27-30

Engle D, Bodine T, Stritzke J (2006) Woody plant community in the cross timbers over two decades of brush treatment. Rangeland Ecol Manag 59:153-162

ENMRD Forestry Division (2010) New Mexico Statewide Natural Resource Assessment and Strategy and Response Plans. Energy, Minerals, and Natural Resources Department, Santa Fe

EWG (Environmental Working Group) (2015) Farm Subsidy Database., Available from https://farm.ewg.org/index.php (Accessed 11/2015)

Fagin T (2016) Fieldnotes, Cimarron County, OK and Union County, NM

Fry J, Coan M, Home C, Meyer D, Wickham J (2009) Completion of the National Land Cover Database (NLCD) 1992-2001 Land Cover Change Retrofit product. U.S. Geological Survey Open-File Report 1379

Fuhlendorf S, Archer S, Smeins F, Engle D, Taylor C (2008) The combined influence of grazing, fire, and herbaceous productivity on tree-grass interactions. In: Van Auken O (ed) Western North American Juniperus communities: a dynamic vegetation type. Springer, New York, pp 219-238

Fulendorf S, Woodward A, Leslie D, Shackford J (2002) Multi-scale effects of habitat loss and fragmentation on lesser prairie-chicken populations. Landsc Ecol 17:617-628

GLP (2005) Science Plan and Implementation Strategy, IGBP Report 35/IHDP Report 19. IGBP Secretariat, Stockhokm

Gökyer E (2013) Understanding landscape structure using landscape metrics. In: Ozyavuz M (ed) Advances in landscape architecture., InTech

Graham A, Fagin T, Vadjunec JM, Phillips B (2013) Persistent drought, land tenure, and land-cover change in the Southern Great Plains: a case study from Cimarron County, OK and Union County, NM. Paper presented at the Association of American Geographers (AAG) Annual Meeting, Los Angeles

Griffin G, Omernik J, McGraw M, Jacobi G, Canavan C, Schrader T, Mercer D, Hill R, Moran B (2006) Ecoregions of New Mexico (color poster with map, descriptive text, summary tables, and photographs). U.S. Geological Survey, Reston

Harding County (2016) Canadian River Riparian Restoration Project., Available from http://www.hardingcounty.org/about/federal-agencies/canadian-riverriparian-restoration-project/ (Accessed 4/16)

Homer C, Dewitz J, Yang L, Jin S, Danielson P, Xian G, Coulston J, Herold N, Wickham J, Megown K (2015) Completion of the 2011 National Land Cover Database for the conterminous United States-representing a decade of land cover change information. Photogramm Eng Rem S 81(5):345-354

Horncastle V, Hellgren E, Mayer P, Ganguli A, Engle D, Leslie D (2005) Implications of invasion by Juniperus virginiana on small mammals in the southern Great Plains. J Mammal 86(6):1144-1155

Houghton R (1994) The worldwide extend of land use change. Bioscience 44(5): 305-313

IPCC (2013) Fifth Assessment Report of the Intergovernmental Panel on Climate Change. Cambridge University Press, Cambridge

Jackson L, Strauss R, Firestone M, Bartolome J (1990) Influence of tree canopies on grassland productivity and nitrogen dynamics in deciduous oak savanna. Agric Ecosyst Environ 32:89-105

Johnson F, Hoagland B (1999) Catalog of woody plant of Oklahoma. Oklahoma Biological Survey., Available from http://www.biosurvey.ou.edu/shrub/ shrubndx.htm (Accessed 9/2015)

Kasperson J, Kasperson R, Turner B II (1996) Regions at risk: exploring environmental criticality. Environment 38:5-29
Lindsey R (2008) Devastating drought settles on the High Plains., NASA's Earth Observatory, Available from http://earthobservatory.nasa.gov/Features/ OklahomaDrought/. Accessed 9 Aug 2009

Lowitt R (2006) American outback. Texas Tech University Press, Lubbock

McGarigal K (2015) Fragstats Help. University of Massachusetts, , Available from http://www.umass.edu/landeco/research/fragstats/documents/fragstats.help. 4.2.pdf(Accessed 9/2015)

McKinley D, Norris M, Blair J, Johnson L (2008) Altered ecosystem processes as a consequence of Juniperus virginiana L. encroachment into North American tallgrass prairie. In: Van Auken O (ed) Western North American Juniperus communities: a dynamic vegetation type. Springer, New York

Miller R, Rose J (1995) Historic expansion of Juniperus occidentalis (Western Juniper) in southeastern Oregon. Great Basin Nat 55:37-45

New Mexico State Land Office (2016a) Obtaining a lease on agricultural lands., Available from http://www.nmstatelands.org/obtaining-a-lease.aspx (Accessed 4/2016)

New Mexico State Land Office (2016b) Forest and watershed. Available from http://www.nmstatelands.org/forest-watershed-health.aspx (Accessed 4/2016)

Oklahoma Ad Valorem (2006) Forum. 15(2):4

Ostrom E (2005) Understanding institutional diversity. Princeton University Press, Princeton

Paysen T, Ansley R, Brown J, Gotffroed G, Haase S, Harrington M, Narog M, Sackett S, Wilson R (2000) Fire in western shrubland, woodland and grassland ecosystems. In: Brown J, Smith J (eds) Wildland fire in ecosystems: effects of fire on flora. USDA Forest Service General Technical Report RMRSGTR, Ogden

Richards J (1990) Land transformation. In: Turner (ed) The earth as transformed by human action. Cambridge University Press, Cambridge

Savage C (2004) Prairie: a natural history. Greystone Books, Vancouver

Schole R, Archer S (1997) Tree-grass interaction in savannas. Annu Rev Ecol Syst 28:517-544

Sørensen R, Zinko U, Seibert J (2006) On calculations on the topographic wetness index: evaluation of different methods based on field observations. Hydrol Earth Syst Sci 10:101-112

Stone-Jovicich S (2015) Probing the interfaces between the social sciences and social-ecological resilience: insights from integrative and hybrid perspectives in the social sciences. Ecology and Society 20(2):25

Turner B II (2002) Toward integrated land-change science: advances in 1.5 decades of sustained international research on land-use and land-cover change. In: Steffen W, Jager J, Carson D, Bradshaw C (eds) Challenges of a changing Earth: proceedings of the Global Change Open Science Conference. Amsterdam, Springer

U.S. Census Bureau (2015a) Quickfacts, Cimarron County, OK., Available from https:// www.census.gov/quickfacts/table/PST045214/40025,35059,00 (Accessed 4/2015)

U.S. Census Bureau (2015b) Quickfacts, Union County, NM., Available from https:// www.census.gov/quickfacts/table/PST045214/35059,00 (Accessed 4/2015)

U.S. Drought Monitor (2015) United States Drought Monitor. A project of the National Drought Mitigation Center (NDMC), The U.S. Department of Agriculture (USDA), and National Oceanic and Atmospheric Association (NOAA)., Available at http://droughtmonitor.unl.edu/ (Accessed 9/2015)

United Nation (2006) The Millennium Development Goals Report 2006. United Nations, New York

USDA-NASS (2014) Census of Agriculture: United States Summary and State Data. United States Department of Agriculture National Agricultural Statistics Service., Available from https://www.agcensus.usda.gov/Publications/2012/ Full_Report/Volume_1,_Chapter_1_US/usv1.pdf (Accessed 9/2015)

USGS GAP Analysis Program, U.S. Geological Survey (2012) Protected Areas Database of the United States (PADUS) version 1.3 combined Feature Class., Available from http://gapanalysis.usgs.gov/padus/data/ (Accessed 9/2015)

Vadjunec J (2015) Fieldnotes, Cimarron County, OK and Union County, NM

Vadjunec J, Sheehan R (2010) Ranching and state school land in Cimarron County, Oklahoma. Great Plains Res 20:163-177

Vadjunec J, Fagin T, Colston N, Graham A, Wenger K (2015) Contested Frontiers: governance, land use/land-cover change (LULCC), and vulnerability to drought in the grasslands of the American West. Paper presented at the Annual Meeting of the Association of American Geographers conference, Chicago

Van Auken O (2009) Causes and consequences of woody plant encroachment into western North American grasslands. J Environ Manage 90(10):1-42

Vogelmann J, Howard S, Yang L, Larson C, Wylie B, Van Driel J (2001) Completion of the 1990s National Land Cover Data Set for the conterminous United States. Photogramm Eng Rem S 67:650-662 
Walker B, Gunderson L, Kinzig A, Folke C, Carpenter S, Schultz L (2006) A handful of heuristics and some propositions for understanding resilience in socialecological systems. Ecology and Society 11(1):13, [online] URL: http://www. ecologyandsociety.org/vol11/iss1/art13/

Wenger K (2015) Land Change and Vulnerability to Drought: Impact and Growth of Center Pivot Irrigation in Union County, NM and Cimarron County, OK. MS Thesis. Oklahoma State University, Stillwater, OK.

Wilcox B (2008) Juniperus woodlands and the water cycle on karst rangelands. In: Van Auken O (ed) Western North American Juniperus communities: a dynamic vegetation type. Springer, New York, pp 202-215

Wisner B, Blaikie P, Cannon T, Davis I (2004) At risk: natural hazards, people's vulnerability and disasters. Routledge, London

Woods A, Omernik J, Butler D, Ford J, Henley J, Hoagland B, Arndt D, Moran B (2005) Ecoregions of Oklahoma (color poster with map, descriptive text, summary tables, and photographs). U.S. Geological Survey, Reston

\section{Submit your manuscript to a SpringerOpen ${ }^{\circ}$ journal and benefit from:}

- Convenient online submission

- Rigorous peer review

- Immediate publication on acceptance

- Open access: articles freely available online

- High visibility within the field

- Retaining the copyright to your article

Submit your next manuscript at $\boldsymbol{s p r i n g e r o p e n . c o m ~}$ 